УДК 398

ББК $82.3(2)$
ФОЛЬКЛОРНЫЙ АРХИВ

И ИСТОРИЧЕСКАЯ ДЕЙСТВИТЕЛЬНОСТЬ (НА МАТЕРИАЛАХ АРХИВОВ ИНСТИТУТА ЯЛИ КарНЦ РАН)

(C) 2020 г. В.П. Кузнецова, Е.В. Марковская

Карельский научный иентр Российской академии наук, Петрозаводск, Россия

Дата поступления статьи: 22 июля 2019 г. Дата публикации: 25 декабря 2020 г.

DOI: https://doi.org/IO.22455/2500-4247-2020-5-4-338-357

Исследование выполнено в рамках темы «Фольклорные традици и рукописная книжность Европейского Севера: источниковедение, текстология, поэтика, этнографический контекст» № AAAA-AІ8-ІІ80зог9оо94-6

Аннотащия: Рассматривается содержание одного из крупнейших фольклорных архивов России, принадлежащего Институту языка, литературы и истории Карельского научного центра РАН. Систематическая собирательская работа, проводившаяся на протяжении более чем гоо лет, способствовала созданию фондов, отражающих исторические события целой эпохи. Фольклорные коллекции содержат материалы, свидетельствующие о времени, когда проявился интерес к «классическому» фольклору. В г930-е гг. появились новые формы эпического творчества - так называемые «новины». В Архиве сохранились произведения этого жанра и документы о работе с народными исполнителями. В годы Великой Отечественной войны создавались произведения лагерного фольклора узниками финских концлагерей; возродился такой жанр, как причитания. В послевоенное время исследователям было указано на необходимость заниматься «советским» фольклором, а не «застывшими» формами народного творчества. Свидетелем своего исторического времени являются архивные материалы, собранные среди представителей депортированного народа - финнов-ингерманландцев. Во второй половине XX в. продолжилось идеологическое давление на фольклористику.

Ключевые слова: фольклор, архив, русские, карелы, вепсы, финны, ижора, фонды, жанры, идеология, война, история, коллекции, Институт ЯлИ.

Информация об авторах: Валентина Павловна Кузнецова - кандидат филологических наук, старший научный сотрудник, Институт языка, литературы и истории, Карельский научный центр Российской академии наук, ул. Пушкинская, д. II, I859Iо г. Петрозаводск, Россия. ORCID ID: https://orcid.org/oooo-ooo2-I075-993X. E-mail: v.kuznetsova2oro@yandex.ru

Елена Владимировна Марковская - кандидат филологических наук, научный сотрудник, Институт языка, литературы и истории, Карельский научный центр Российской академии наук, ул. Пушкинская, д. II, І859Іо г. Петрозаводск, Россия. ORCID ID: https://orcid.org/oooo-ooo2-667I-240I. E-mail: greek23@mail.ru

Для цитирования: Кузнецова В.П., Марковская Е.В. Фольклорный архив и историческая действительность (на материалах архивов Института ЯЛИ КарНЦ РАН) // Studia Litterarum. 2020. T. 5, № 4. C. 338-357. https://doi.org/IO.22455/2500-4247-2020-5-4-338-357 


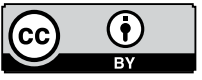

This is an open access article distributed under the Creative Commons Attribution 4.0 International (CC BY 4.0)

\section{FOLKLORE ARCHIVE AND HISTORICAL REALITY (BASED ON THE ARCHIVE MATERIALS OF THE INSTITUTE OF LANGUAGE, LITERATURE AND HISTORY OF THE KARELIAN RESEARCH CENTER, RAS)}

\author{
(C) 2020. V.P. Kuznetsova, E.V. Markovskaya \\ Karelian research centre of Russian Academy \\ of Sciences, Petrozavodsk, Russia \\ Received: July 22, 2019 \\ Date of publication: December 25, 2020
}

Acknowledgements: The study was carried out under the project No. AAAA-AI8-II8030190094-6.

Abstract: The paper discusses the content of one of the largest folklore archives in Russia belonging to the Institute of Language, Literature and History of the Karelian Scientific Center of the Russian Academy of Sciences. Systematic work of collecting folklore, carried out for more than Ioo years, contributed to the creation of archives reflecting the historical events of an entire era. In the I930s a new historical period began, giving life to the new forms of epic art - the so-called "novinas," held in the Archive. During the Great World War, prisoners of the Finnish concentration camps created the so-called pieces of camp folklore, reviving the genre of lamentation. In the postwar period, researches were urged to deal with "Soviet" folklore, and not with the "frozen" forms of folk art. The archival materials collected among the representatives of deported people - Ingrian Finns - bear witness of the historical time. In the second half of the $2 \mathrm{O}^{\text {th }}$ century ideological pressure in the folkloristic studies continued, as superstitions and prejudices were sought to be eradicated, and the collection of folklore reflecting folk religious beliefs was not welcomed.

Keywords: folklore, archive, Russians, Karelians, Vepsians, Finns, Izhora, funds, genres, ideology, war, history, collections, Institute of Language, Literature and History.

Information about the authors: Valentina P. Kuznetsova, PhD in Philology, Senior Researcher, Institute of Language, Literature and History, Karelian Research Center of the Russian Academy of Sciences, Pushkinskaya II, I859Io Petrozavodsk, Russia. ORCID ID: https://orcid.org/oooo-0002-I075-993X.

E-mail: v.kuznetsova2oı。@yandex.ru

Elena V. Markovskaya, PhD in Philology, Researcher, Institute of Language, Literature and History, Karelian Research Centre of the Russian Academy of Sciences, Pushkinskaya II, I859Io Petrozavodsk, Russia.

ORCID ID: https://orcid.org/oooo-0002-667I-240I. E-mail: greek23@mail.ru

For citation: Kuznetsova V.P., Markovskaya E.V. Folklore Archive and Historical Reality (Based on the Archive Materials of the Institute of Language, Literature and History, Karelian Research Center RAS). Studia Litterarum, 2020, vol. 5, no 4, pp. 338-357. (In Russ.) https://doi.org/IO.22455/2500-4247-2020-5-4-338-357 


\section{Содержание фольклорного архива}

Фольклорные архивы воспринимаются не только исследователями, но, пожалуй, и широким кругом пользователей, прежде всего, как собрания памятников фольклора - эпических произведений, сказок, различных нарративов, песен, причитаний и т. д., как средоточие духовных ценностей народа. Известно, что фольклор в определенной мере отражает исторические реалии. Это может относиться к отдельным произведениям, к целому жанру, к новообразованиям, возникшим в системе уже устоявшегося, традиционного жанра и т. д. Еще в г96о-е гг. В.Я. Пропп указывал, что фольклор восходит к исторической действительности и отражает ее и что одна из задач исследователей состоит в том, чтобы показать это на том материале, который они изучают [I5]. В значительной степени это относится и к фольклорному архиву, о котором пойдет речь в данном исследовании, поскольку содержание хранящихся в нем коллекций тесно связано и с историей общества того времени, когда фольклорные произведения создавались, и с современной тому времени идеологией.

Институт языка, литературы и истории (далее - Институт), входящий в состав Карельского научного центра РАН, является старейшим научным учреждением Республики Карелия, образованным в г93І г. Институт обладает одним из крупнейших в России фольклорных архивов (далее Архив), в котором хранятся материалы, относящиеся к периоду с г9Іо г. по настоящее время. Коллекции произведений устного народного творчества были собраны на территории проживания прибалтийско-финских народов (карелов, вепсов, ингерманландских финнов, ижоры) Российского СевероЗапада и русского населения, проживающего на этой же территории, ко- 
торую в среде специалистов принято называть «Русский Север». Ранние коллекции, датируемые І9Іо-І955 гг., содержат записи, произведенные от руки. Впоследствии, когда собиратели стали пользоваться в своей работе магнитофонами, Архив стал пополняться текстовыми расшифровками звуковых записей. Все собрание делится на два раздела по языковому признаку: фольклор прибалтийско-финских народов (I75 коллекций) и северно-русский (2І2 коллекций). Помимо рукописного собрания, хранящегося в Научном архиве Карельского научного центра РАН, фольклорный архив Института включает также Фонограммархив. Наиболее ранние фонограммы датируются концом 30-х - началом 40-х гг. XX в. Это гибкие грампластинки, изготовленные из использованной рентгеновской пленки. Впоследствии собиратели записывали произведения фольклора, этнографические сведения и образцы речи на аналоговые магнитофоны, а начиная с последнего десятилетия XX в. на цифровую звукозаписывающую технику. Фонд фонограмм насчитывает сейчас более 4000 единиц хранения (это гибкие пластинки, катушки с магнитофонной лентой, компакт-кассеты, CDдиски, нумерованные папки со звуковыми файлами, хранящиеся на жестком диске). В конце г990-х гг. стали производиться полевые видеозаписи фольклора. Собрание видеозаписей насчитывает в настоящее время около Іооо часов. Ценность этого архива определяется не только полнотой и составом фольклорных жанров народов Российского Северо-Запада, но и систематичностью экспедиционных работ, благодаря которым по собранным коллекциям можно представить картину бытования фольклорных жанров целой эпохи, их жизнь и постепенное угасание, вполне естественное, связанное с изменением исторических реалий, и в то же время, появление новых образований в устном народном творчестве.

Задача настоящего исследования - не только раскрыть богатство и ценность Архива, но и показать, что хранящиеся в нем фольклорные коллекции действительно хранят память об историческом периоде, начиная с первой трети XX в. и до начала века XXI.

Первые фольклорные записи, поступившие в Архив, были сделаны любителями-краеведами в І9Іо-І930 гг. и хранились до того времени, когда был создан Институт, в Карельском бюро краеведения. Собирательская работа того времени не носила систематического характера, но благодаря энтузиазму краеведов-любителей Архив пополнился ценными коллекциями. 
К этому периоду относится собрание поморского краеведа из с. Сумпосад И.М. Дурова и членов организованных им краеведческих ячеек, которое включает записи с г9Іо по І938 гг. (научный архив КарНЦ РАН. Ф.І. Оп. І. Колл. 27, 28, 34, 40), всего это более 8оо произведений разных жанров.

Среди материалов первой трети XX в. отдельное место занимает собрание учительницы-краеведа Е.И. Ржановской. Она занималась сбором произведений фольклора в Заонежье (Медвежьегорский район Карелии). В Архиве хранятся ее ценнейшие коллекции детского фольклора. Часть материалов Е.И. Ржановской и И.М. Дурова были изданы в сборнике детского фольклора, составленного С.М. Лойтер [9].

\section{Собирание и изучение фольклора}

\section{в свете идеологических задач г930-х гг.}

Новый исторический период, который отразился на содержании архива, начался в 1930 гг. Перед собирателями были поставлены не только сугубо научные, но и идеологические задачи.

Организация Карельского научно-исследовательского института (в настоящее время Институт языка, литературы и истории - ИЯлИ КарНЦ РАН) в І93І г. положила начало новому этапу собирательского дела. В Республике Карелия началось становление профессиональной работы фольклористов, этнографов, языковедов. Начали закрепляться навыки научной собирательской работы. Перед сотрудниками вновь созданного Института была поставлена цель - сбор материалов, свидетельствующих о процессе зарождения новых и отмирании старых жанров в сельской среде; фиксация фольклора на тему Гражданской войны в России. Эти задачи были востребованы советской идеологией, заставлявшей исследователей искать в деревне произведения, воспевающие новую счастливую жизнь и новых героев. Те же тенденции исследователи хотели найти и в классическом русском эпосе позднейшего времени.

В начале І930-х гг. собирательская работа была продолжена Фольклорной секцией Института этнографии Академии Наук СССР и Карельским научно-исследовательским институтом [5, с. 540-570]. Необходимо было вновь обследовать места, где уже побывали комплексные экспедиции из Москвы и Ленинграда; одной из задач собирателей было изучение состояния эпической традиции и ее социальной функции в совре- 
менных условиях. Была поставлена и такая цель, как повторная фиксация былин сказителей, от которых уже производились записи, и поиск новых исполнителей. В русле новых идеологических установок фиксация вариантов классических сюжетов расценивалась как не только интересное и значительное звено, необходимое для изучения основ сюжета, но и как проявление «живой творческой энергии народных масс» - писала известный эпосовед А.М. Астахова [3, с. 9].

Первые значительные коллекции записей былин, поступившие в Архив, были собраны студентами этнографического отделения Ленинградского историко-лингвистического института в Заонежье (научный архив КарНЦ РАН. Ф. І. Р. VI. ОП. І. Д. 6о-94). Согласно давней традиции русской фольклористики, сотрудники Института ЯлИ проводили собирательскую работу в исторических районах Карелии: Заонежье, Пудожье, Поморье. Большое количество собранного материала позволило осветить вопросы эволюции русского эпоса в поздний период его бытования, увидеть изменения в репертуаре и в самих произведениях. По поводу новых тенденций в эпосе позднейшего времени мнения ведущих ученых разделились: одни считали, что на былинах позднейшей записи совсем незначительно сказались творческая переработка и приспособление к новым социальным условиям старых сюжетов, другие наоборот, считали, что в эпических песнях наблюдается усиление социальных моментов старого эпоса вследствие культурного роста и более глубокого понимания классовых взаимоотношений прошлого.

В конце г930-х гг. начался «подъем» и «расцвет», как посчитали тогда исследователи, в области эпического творчества. Это было рождение нового современного «эпоса», так называемых «новин». В разных коллекциях Архива их содержится около 50о. Эпоха «новин» относится к первой половине XX в. С г940-х гг. началась дискуссия о принадлежности «новин» к фольклорным произведениям и их художественной ценности. После смерти Сталина обсуждения продолжились. В это время многие фольклористы, включая тех, кто работал со сказителями, помогая создавать новины, признали, что эти новые произведения скорее являются имитациями или авторскими литературными произведениями. И хотя большинство исследователей уже не относило новины к фольклору, в некоторых сборниках они продолжали встречаться еще в конце г96о-х гг. В настоящее время 
несмотря на то, что деятельность по созданию новин осталась в далеком прошлом, интерес к ним остался. Подтверждением этому могут служить современные публикации российских ученых [7; 4; 6 и др.], а также исследование американского слависта Фрэнка Миллера [г3]. В Архиве сохранились не только тексты новин, но и документы, дающие представление о том, как происходила работа со сказителями. Согласно советской идеологии, именно выдающиеся народные исполнители должны были распространять идеи «новой жизни» в народе и формировать нужное отношение к событиям, происходящим в стране. Сказители приглашались на съезды, где им объясняли, что и как нужно писать. Идеологическая работа со сказителями включала разнообразную просветительскую деятельность: переписка, поездки к сказителям, их учеба, посылка газет и книг, организация выездов в города с посещением кино, театров и различных экскурсий, установка радио на дому сказителей, беседы на политические и литературные темы. Культурно-массовая работа такого рода особенно широко стала развертываться в начале г938 г., вплоть до начала Великой Отечественной войны. Инициатива этой работы со сказителями исходила от ленинградских фольклористов из Пушкинского Дома. Под их руководством подобная деятельность осуществлялась и сотрудниками Карельского научно-исследовательского Института. Директорам сельских школ, в сельсоветы и правления колхозов было разослано 4ІІ писем и памятных записок. Одно из них было опубликовано в работе Т.И. Сенькиной. В письме сотрудники Института просили сообщить: «...имеются ли в вашем сельсовете граждане, знающие много сказок, былин, рун, пословиц, песен и талантливые граждане, составляющие сами эти песни и сказки. Сообщите их фамилию, имя и отчество и точный адрес. Ваше сообщение окажет большую помощь Институту, так как записыватели поедут к определенным людям, выявленным при Вашей помощи. Это ускорит выпуск намеченных Институтом сборников. Крупные сказители будут вызываться в Институт для работы с ними (за подписью И.о. Директора КНИИК Машезерского и научного работника Антиповой)» [16, с. г30-I3I]. Сказителей обучали грамоте, чтобы они могли записывать свои произведения. Идея этой работы сводилась к попытке научить народных певцов славить современную жизнь. Сказители были готовы сочинять новые произведения даже о незнакомых героях и событиях и исправлять свои тексты под руководством сотрудников редакций 
газет. Неграмотным крестьянским поэтам читали заметки из прессы, а они должны были сочинять в стиле эпических песен и плачей произведения на заданные темы. Так появлялись авторские самодеятельные произведения о руководителях советского государства, о событиях Гражданской войны, о Беломорканале и т. д.

Марксистско-ленинская идеология большие надежды возлагала на формирование в народе положительного отношения к действиям власти при помощи нового «советского фольклора». Именно этим можно объяснить столь пристальное внимание к сказителям и разработку жанра «новин». Со временем организаторам работы по созданию новин становилось ясно, что «советский фольклор» не получил распространения в народной среде, он является скорее авторским трудом, зачастую не имеющим поэтической ценности. И тем не менее коллекция новин, хранящаяся в Архиве, представляет большую ценность не только как свидетельство неудачного опыта давления коммунистической идеологии на сказителей, но и как материал своей эпохи, который должен получить объективную оценку в исследованиях фольклористов, литературоведов, историков.

Карельские коллекции І930-х гг., так же как и русские, отражают идеологическое давление на фольклористику: в это время собиратели активно сотрудничали с народными исполнителями, устанавливали длительные корреспондентские связи. Во время полевых выездов велась активная разъяснительная работа, целью которой было одно: получить произведение, соответствующее новой идеологии. Благодаря этому обстоятельству рождались песни и плачи о вождях новой эпохи, о героях Гражданской войны, о счастливой жизни карельского крестьянства. Карелы, не вполне понимавшие русский язык, использовали русскую лексику: буржуи, кулаки, советская власть и т. д. Сказители искусственно соединяли архаичный и современный для них поэтический материал, например, Сталин представлен как «великий человек, герой отважный», трактор изображен как жеребец с железными ногами, выкованный эпическим кузнецом Илмариненом [I4, с. 50-57].

Среди многочисленных записей І930-г940-х гг. большое место принадлежит такому жанру народной поэзии, как причитания. Этот жанр характерен для фольклора многих народов мира, но особенно он развит у финноязычных народов и русских северо-восточной Европы. 
В г930-е гг. архивные фонды пополнились крупными коллекциями причитаний. В основном это были произведения традиционного стиля и содержания, исполнявшиеся в составе похоронного, свадебного обрядов, а также окказиональные. В сложившихся к этому времени исторических условиях в значительной степени изменилось отношение исследователей к этому жанру. В причитаниях обращали внимание на появление новых, гражданских и политических мотивов, а не на традиционные мотивы скорби, утраты, любви и т. п. Причитаниям стали приписывать роль произведений, наглядно показывающих тяжесть народной жизни и освобождение от экономического и политического гнета с приходом советской власти. В это время было создано немало плачей и сказов о вождях и героях Советского Союза, в которых соединялись традиционные элементы причитаний и эпических песен с сюжетами современной жизни, заметна большая роль личного творчества исполнительниц. В отличие от новин, создателями которых были как мужчины, так и женщины, плачи нового содержания создавали исключительно женщины, как этого требовала древняя традиция. Исследователи признавали, что и в современных записях сохранялся поэтический канон причитаний, весь арсенал изобразительных средств, выработанных в течение веков местными школами причитальщиц. В І950-1960-е началось активное изучение причитаний карельскими учеными. В эти же годы возродился интерес к обрядовой поэзии карелов среди финских исследователей [г7; и др.].

\section{Материалы о событиях Великой Отечественной войны в фольклорных коллекциях Архива}

До начала Великой Отечественной войны, в первой половине I94I г., сотрудники Института активно участвовали в экспедициях по Карелии.

Во время войны, в период с І94I по г944 гг., значительная часть Республики Карелия, тогда называвшейся Карело-Финской Советской Социалистической Республикой, была оккупирована финскими войсками. Часть людей не успела эвакуироваться и осталась на этой территории.

Финским военным предписывалось дружественно обращаться с карельским населением, а русских задерживать и отправлять в концентрационные лагеря. Представители финно-угорских народов рассматривались в качестве будущих равноправных граждан «Великой Финляндии». По 
данным, приведенным историком В.Г. Макуровым, на территории КарелоФинской ССР было организовано го концентрационных лагерей, большая часть которых находилась в Петрозаводске. Здесь содержалось свыше 20 тыс. человек. В них, вследствие тяжелых условий жизни (непосильных работ, голода, болезней), а также расстрелов, по разным данным, погибло от 4000 до 7000 человек [Іо, с. 29]. В Архиве сохранилась коллекция под названием «Лагерные песни, записанные от лиц, бывших в оккупации у финнов и заключенных в концлагеря в период I94I-I944 гг.», датированная I944 г. [II]. Коллекция содержит свыше 400 произведений. Это самодеятельные песни, романсы, тюремные песни, частушки, стихи из девичьих альбомов.

Фольклорное наследие Карелии военного времени частично было опубликовано. В г945 г. в Петрозаводске вышла книга В.Г. Базанова «За колючей проволокой... [г], в которую он включил наиболее характерные плачи о фашистской неволе, собранные им среди узников лагерей. В 1944 г. В.Г. Базанов и А.П. Разумова совершили экспедицию в Заонежье, на этот раз вовсе не для поиска мастеров исполнения эпических песен, а для записи народных плачей о войне. Спустя почти 20 лет был опубликован сборник, в который вошли архивные материалы, собранные в этой послевоенной экспедиции [2].

К фольклорным материалам, в датировках которых присутствуют годы войны, относятся I8 коллекций русского и I5 коллекций фольклора прибалтийско-финских народов. Но большей частью эти коллекции содержат записи, сделанные в предвоенные месяцы и первое послевоенное время. К записям военного периода относится коллекция, включающая более тысячи фольклорных текстов на карельском языке, полученных от Вяйне Кауконена, который собрал их в 1942-І944 гг. на территории оккупированной Карелии [научный архив КарНЦ РАН. Ф. І. Оп. 2. Колл. 5. (Подлинники хранятся в Архиве Финского Литературного общества)]. В Научном архиве сохранилось также большое собрание малых фольклорных жанров, собранных финскими коллегами среди вепсского и карельского населения с 1902 по г96о гг., полученное в обмен на карельские материалы из фольклорных фондов Института (научный архив КарНЦ РАН. Ф. І. Оп. 2. Колл. I45, I46, I47). 


\section{Материалы Архива, отражающие идеологию послевоенного времени}

Материалы послевоенного времени отражают пристальное внимание, которое уделялось военному фольклору. В Архив поступали записи песен о войне, частушки, воспоминания очевидцев. Большое внимание уделялось устному прозаическому рассказу. Этот жанр являлся самой простой и доходчивой формой самодеятельного художественного творчества, и особая роль в нем принадлежала теме Великой Отечественной войны, чрезвычайно актуальной в послевоенное время. Эти рассказы можно разделить на две группы - рассказы о героях и рассказы о ярком случае на войне. Крупные коллекции были собраны научным сотрудником Института К.В. Чистовым среди девушек-учащихся Петрозаводского ремесленного училища. Это альбомы, песенники, где встречаются не только авторские песни, популярные в середине XX в., но и песни-переделки, частушки, самодеятельные песни о Великой Отечественной войне. Такого рода материал содержится и в коллекции, собранной К.В. Чистовым в г. Сеге́жа в г949 г. Здесь есть мемораты, самодеятельные песни и стихи, частушки, переделки военно-патриотических песен, романсы и другие произведения [8].

Возникает вопрос, почему в то время, когда традиционный фольклор еще существовал во всем своем богатстве и разнообразии, нужно было фиксировать подобного рода материал? Объяснение кроется в событиях, которые происходили в то время. В стране проводилась повсеместная борьба с космополитизмом и формализмом, коснувшаяся и сотрудников Института. Проводились проверки партийными органами, в результате которых выносились постановления о недостатках в работе исследователей, поскольку им было необходимо руководствоваться постулатами о партийности идеологии и заниматься изучением советского фольклора. По этой причине был снят со своей должности заведующего отделом литературы Института К.В. Чистов. Доходило дело до преследования сотрудников, обвинявшихся в преклонении перед «застывшими» формами устного народного творчества и находившихся на «антинаучных» «метафизических» позициях. Примером может служить судьба Е.М. Мелетинского, работавшего в Карело-Финском государственном университете (г946-г949). Его обвинили в космополитизме и не только освободили от должности заведующего кафедрой, но и арестовали [І2]. Это был конец І940-х гг. По прошествии 
нескольких лет после смерти Сталина, когда в стране началась «оттепель», собирательская работа восстановилась, и исследователи снова стали проводить экспедиции в районы Российского Северо-Запада, где еще можно было зафиксировать богатейший традиционный фольклор.

Но еще в середине XX в. фольклористика ощущала влияние коммунистической идеологии. Так, существовал негласный «запрет» на некоторые жанры устного народного творчества. Сюда относились устные рассказы о мифологических персонажах: духах-«хозяевах» дома, хлева, леса, воды и т. д., в которых проявлялись древние народные представления. В стране закрывались и уничтожались церкви, искоренялась православная религия, а также народные верования, считавшиеся проявлениями суеверий и предрассудков. Поэтому в ранних коллекциях, хранящихся в Архиве, практически отсутствует мифологическая проза. Другой жанр, не соответствующий советским нормам, - это заговоры, которыми народные целители пользовались с древних времен. Не соответствовали коммунистической идеологии «духовные стихи» - народная религиозная поэзия, которой не уделялось должного внимания со стороны собирателей. Записи этих произведений были чаще случайными, в то время их не собирали целенаправленно. Наибольший интерес к духовным стихам проявился только в 70-9о-е гг. $\mathrm{XX}$ в., когда удалось захватить последние остатки этих эпических произведений.

Свидетелем своего исторического времени является собрание устного народного творчества и памятников языка депортированных прибалтийско-финских народов (г930-е гг.). Это коллекции, собранные среди финнов-ингерманландцев и ижоры, имеющие большое общественное и научное значение. Немало представителей этих народов поселились на Северо-Западе России. Ижорский язык находится на грани исчезновения, поэтому наличие хотя бы небольшого архивного фонда, особенно звуковых записей, чрезвычайно актуально для сегодняшнего времени. Исследователи Института собирали материалы как на исконной территории проживания этих народов, так и в населенных пунктах Карелии, где проживают переселенные со своей родины представители этих национальностей. Первые записи относятся к началу г950-х гг., они были сделаны в Петрозаводске. В конце I950-х гг. сотрудники Института и любители-краеведы, неравнодушные к судьбе ингерманландского народа, собирали фольклорное насле- 
дие в разных районах Карелии и в Петрозаводске. Нередко исследователи записывали материалы от своих родителей, родственников и знакомых, чтобы сохранить особенности говоров, произведения устного народного творчества, а также историю своего народа. С г960-х гг. стали проводиться экспедиции в Ленинградскую область. В течение г968-г975 гг. по ижорам был собран значительный фольклорный и языковой материал. В настоящее время финский и ижорский фонды оцифрованы полностью и хранятся не только в Фонограммархиве Института ЯЛИ, но и в Лондонском университете, в Архиве исчезающих языков.

\section{Материалы Архива второй половины XX в.}

\section{Новые методы и задачи собирательской работы}

Коллекции последней трети XX в. отличаются значительным расширением жанрового состава поступивших в Архив произведений. Фольклористы стали больше записывать этнографического материала и больше внимания уделялось личности исполнителя. В этот период сделано наибольшее количество записей духовных стихов, заговоров и произведений мифологической прозы. Значительное увеличение объема поступлений было обусловлено тем, что с 1957 г. сотрудники получили возможность работать с катушечными магнитофонами в экспедициях. С этого времени коллекции стали составляться сначала частично, а с конца I970-х гг. в основном из текстовых расшифровок. Расширилась территория обследования, сотрудники собирали фольклорные материалы не только на территории Карелии, но и в Архангельской, Мурманской, Вологодской и других областях Российского Северо-Запада. Интенсивно изучались фольклорные традиции в селах, расположенных на берегах Белого моря. Имеются редкие звуковые записи эпических песен и поздних духовных стихов от представителей старообрядческой общины села Усть-Цильма (Республика Коми).

Фольклор саамов Кольского полуострова фиксировался в основном языковедами, занимавшимися изучением четырех диалектов этого народа. Сбор сведений был начат в 50-е гг. XX в., когда исследователи уже могли пользоваться магнитофонами, поэтому оригиналы практически всех саамских записей хранятся в фондах Фонограммархива Института.

Самую большую часть собрания Фонограммархива составляют записи, производившиеся в районах проживания карелов. Исследователи 
записывали разнообразный по содержанию материал, как фольклорный, так и языковой. Это было особенно актуально, так как для малочисленных народов карелов, вепсов и саамов, не имевших своей письменности, требовалось составление словарей, подготовка исследований, поэтому наличие звуковых записей было особенно необходимо.

Актуальной задачей сегодня является сохранение Архива, в первую очередь звукового, так как магнитная лента имеет ограниченный срок хранения. Благодаря появлению современных технологий, были оцифрованы старые магнитные ленты и грампластинки. При финансовой поддержке различных фондов - Российского гуманитарного научного фонда, БаренцСекретариата и др., Программы гуманитарных исследований Российской академии наук - были проведены работы по проектам, направленным на оцифровку Архива, разработку электронного каталога и web-приложений по Фонограммархиву и Рукописному архиву в сети Интернет сделать Архив доступным как для исследователей, так и для широкого круга пользователей: студентов и преподавателей высших и средних учебных заведений, сотрудников музеев, профессиональных и самодеятельных коллективов, любителей устного народного творчества и т. д.

К настоящему времени оцифрованы не только фонограммы, но и значительная часть коллекций, записанных от руки. Проводится планомерная оцифровка видеозаписей. Оцифрованные рукописные и звуковые коллекции хранятся на сервере Фонограммархива Института ЯЛИ КарНЦ РАН. Создана локальная сеть, позволяющая работать с оцифрованными записями. Была разработана программа Базы данных, ее созданию предшествовала большая работа по разработке и наполнению полей, в том числе наиболее сложного поля «жанр», учитывая разноязыковой материал и разные системы жанров фольклора народов Северо-Запада России [18].

Продолжаются полевые работы по сбору фольклорных и этнографических материалов, в том числе совместно с зарубежными исследователя-

I Информация о Фольклорном архиве ИЯлИ размещена в Интернете на двух web-сайтах. Это сайт «Фонограммархив ИЯЛИ КарНЦ PAH» (URL: http://phonogr.krc.karelia.ru), где дана общая информация об истории Фонограммархива, краткая информация о каждом народе, проживающем на территории Карелии и сопредельных областей, география экспедиций, фотографии исполнителей и собирателей, образцы произведений разных жанров прибалтийско-финских народов России и русских. Сайт «Фольклорный архив Института ЯЛИ КарНЦ РAH» (URL: http://folk.krc.karelia.ru) содержит часть рукописного собрания. 
ми. Изменилась методика работы в полевых условиях: если раньше собиратели записывали фольклор у наиболее талантливых исполнителей, то в настоящее время фиксируется во всей полноте фольклор, сохранившийся в памяти исполнителя на данный момент.

\section{Выводы}

Обобщая вышесказанное, можно сделать выводы не только о данном Архиве, но и более общего характера. Они заключаются в следующем:

На первоначальном этапе собирательской работы для исследователей важно было выявить наиболее интересные и важные жанры фольклора - это в первую очередь эпос, отражающий наиболее характерные черты и духовные ценности этноса. На этом этапе значима была национальная составляющая фольклора, выявлялись мифологические истоки, верования, обычаи и обряды, нашедшие отражение в сюжетах и мотивах фольклорных произведений. Это было важно для развития национальной культуры (литературы, изобразительного, музыкального искусства и т. д.). Общество интересовал вопрос происхождения своих национальных корней, определялись ценности и идеалы, формировавшие самобытность народа.

После Октября I9I7 г. новой власти понадобилось народное признание не тех старых ценностей и идеалов, которые демонстрировал традиционный фольклор, а новой политики, новых вождей. Это породило совсем другие формы народного творчества, отражающие политический контекст своего времени. Архивные материалы, собранные в г930-е гг., свидетельствуют о том, что приспособление к новым социальным условиям традиционных классических сюжетов оказалось невозможным.

Общественно-политическая жизнь нашла отражение и в фольклорных архивах, хранящих произведения, посвященные историческим событиям - Первая мировая война, Великая Отечественная война, депортация народов. Трагические события войны способствовали возрождению традиционного жанра причитаний, имевшего в прошлом массовое распространение на Русском Севере. Собранные материалы свидетельствуют о том, что этот жанр стал не менее массовым, чем в XIX в., когда наблюдался расцвет плачевой культуры в данном регионе. В военные годы получил развитие особый вид народного творчества - лагерный фольклор. В фольклоре этого типа удерживаются установки не только на политический контекст, 
но и на человеческие ценности - свободу, равенство, право жить на своей родной земле и т. д. Тему Великой Отечественной войны отражает и такой жанр, как устный прозаический рассказ, широко распространенный в послевоенное время.

Об идеологическом давлении свидетельствуют архивные коллекции, собранные в период, когда власти вели борьбу с надуманными политическими противниками в среде фольклористов. Указывая специалистам, что нужно собирать, а что нет, они тем самым способствовали появлению в Архиве коллекций произведений, относящихся больше к литературному творчеству, а не к фольклору.

Отсутствие или наличие только единичных записей определенных жанров устного народного творчества в Архиве, негласный запрет не только на изучение, но и на собирание некоторых произведений, основанных на народных религиозных верованиях, также является свидетельством исторической эпохи, когда на фольклористику оказывалось идеологическое давление.

Несмотря на это, а также на трудности военного и послевоенного времени, Архив усилиями специалистов Института к концу XX в. накопил уникальные по своему составу коллекции по фольклору, языкам и этнографии народов Российского Северо-Запада. Благодаря собранным и расшифрованным материалам исследователи Института подготовили фундаментальные исследования в области языкознания, фольклористики, этнографии; подготовлены и изданы словари, опубликованы образцы речи и многочисленные сборники фольклорных произведений.

Фольклорные архивы Института ЯЛИ КарНЦ РАН, благодаря систематически проводившейся собирательской работе на протяжении длительного исторического периода, могут служить подтверждением тезиса о том, что фольклор - это не только средоточие сложившихся национальных ценностей, но и живое творческое явление, и, как всякий живой организм, он может развиваться, угасать, умирать и порождать к жизни новые формы, а также реагировать на изменения исторической действительности. 


\section{Список литературы}

I Базанов В.Г. За колючей проволокой: Из дневника собирателя народной словесности. Петрозаводск: Гос. Изд. Карело-Фин. ССР, г945. 7I с.

2 Базанов В.Г., Разумова А.П. Русская народно-бытовая лирика: Причитания Севера в записях В.Г. Базанова и А.П. Разумовой. М.; Л.: Изд-во АН СССР, І962. 598 с.

3 Былины Севера // Записи, вступ. ст. и коммент. А.М. Астаховой. М.; Л.: Изд-во АН СССР, І938. Т. І. 655 с.

4 Иванова Т.Г. О фольклорной и псевдофольклорной природе советского эпоса // Рукописи, которых не было. Подделки в области славянского фольклора / изд. подгот. А.Л. Топорков, Т.Г. Иванова, Л.П. Лаптева, Е.Е. Левкиевская. М.: Ладомир, 2002. С. 403-43I.

5 Иванова Т.Г. История русской фольклористики XX века: г90о-первая половина I94I г. СПб.: Дмитрий Буланин, 2009. 800 с.

6 Илюха О.П. «Руна о задержании шпиона»: государственная граница в Советском фольклоре и пропагандистском дискурсе г930-х годов // Альманах североевропейских и балтийских исследований. 20I8. Вып. 3. URL: http://nbsr.petrsu.ru/ journal/article.php?id=IIог (дата обращения: 15.07.2019). Козлова И. «Сталинские соколы»: тоталитарная фразеология и «советский фольклор» // Русский политический фольклор: исследования и публикации: сборник / ред. Т. Григорьева. М.: Новое изд-во, 20І3. С. ІІІ-II9.

8 Кузнецова В.П. Экспедиции К.В. Чистова в Карелии // Кунсткамера. 2019. № I (3). C. 23-35.

9 Лойтер С.М. Детский поэтический фольклор Карелии: исследование и тексты. Петрозаводск: Изд-во ПетрГУ, 2013. 440 с. Макуров В.Г. Петрозаводск в годы суровых испытаний I94I-I945. Петрозаводск: Паритет, 2005. 79 c. Марковская Е.В. Лагерный фольклор периода финской оккупации Карелии (194I-I944) // Традиционная культура. 2015. № 2 (58). С. І9-27. Марковская Е.В., Новожилова С.В. Е.М. Мелетинский в Карелии // Фольклор: структура, типология, семиотика. 20I8. Т. I, № I-2. С. 43-54.

I3 Миллер Ф. Сталинский фольклор. СПб.: Академический проект; ДНК, 2006. I90 с.

I4 Миронова В.П. Фольклорные новообразования в репертуаре карельских сказителей 1930-І940 годов // Музыкальная традиция Северной Карелии. Петрозаводск: Изд-во ПГК, 20I3. С. 50-57. Пропп В.Я. Об историзме русского фольклора и методах его изучения // Ученые записки ЛГУ. Л.: Изд-во ЛГУ, г968. № 339. Серия: Филологические науки. Вып. 72. С. 5-25.

I6 Сенькина Т.И. Забытые и неизвестные страницы истории фольклористики Карелии. Очерки и материалы. Петрозаводск: Изд-во КарНЦ РАН, 2оI2. 2I8 с. 
I7 Honko L. Itkuvirsirunous // Suomen kirjallisuus / edited by Matti Kuusi.

Helsinki, Otava: Suomalaisen Kirjallisuuden Seura ja Otava, I963. Vol. I. P. 8I-I24.

I8 Markovskaja E.V. On the experience of creating genre classification of folkloric materials for electronic catalog of folkloric archival depository of ILLH KarRC RAS // European journal of literature and linguistics. 20I6. № 4. P. 68-73. 


\section{References}

Bazanov V.G. Za koliuchei provolokoi: Iz dnevnika sobiratelia narodnoi slovesnosti

[Behind the barbed wire: From the diary of a collector of folk literature]. Petrozavodsk, Gosudarstvennoe izdatel'stvo Karelo-Finskoi SSR, I945. 7I p. (In Russ.)

Bazanov V.G., Razumova A.P. Russkaia narodno-bytovaia lirika: Prichitaniia Severa v zapisiakh V.G. Bazanova i A.P. Razumovoi [Russian folk and household lyrics: Lamentations of the North in the records of V.G. Bazanov and A.P. Razumova]. Moscow, Leningrad, Izdatel'stvo AN SSSR Publ., I962. 598 p. (In Russ.) Byliny Severa [Epics of the North], entries, introd. article and comment. by A.M. Astakhova. Moscow, Leningrad, Izdatel'stvo AN SSSR Publ., I938. Vol. I. 655 p. (In Russ.)

Ivanova T.G. O fol'klornoi i psevdofol'klornoi prirode sovetskogo eposa [On the folklore and pseudo-folklore nature of the Soviet epic]. In: Rukopisi, kotorykh ne bylo. Poddelki v oblasti slavianskogo fol'klora [Manuscripts that did not exist. Forgeries in the field of Slavic folklore], edition prepared by A.L. Toporkov, T.G. Ivanova, L.P. Lapteva, E.E. Levkievskaia. Moscow, Ladomir Publ., 2002, pp. 403-43I. (In Russ.) Ivanova T.G. Istoriia russkoi fol'kloristiki XX veka: I9oo-pervaia polovina I94I g. [History of Russian folklore of the $20^{\text {th }}$ century: 1900 - the first half of I94I]. St. Petersburg, Dmitrii Bulanin Publ., 2009. 800 p. (In Russ.)

Iliukha O.P. "Runa o zaderzhanii shpiona”: gosudarstvennaia granitsa v Sovetskom fol'klore i propagandistskom diskurse I930-kh godov ["The rune about the detention of a spy": the state border in the Soviet folklore and propaganda discourse of the I930s]. In: Al'manakh severoevropeiskikh i baltiiskikh issledovanii, 20I8, vol. 3. Available at: http://nbsr.petrsu.ru/journal/article.php?id=IIoI (accessed I5 July 20I9). (In Russ.)

Kozlova I. "Stalinskie sokoly”: totalitarnaia frazeologiia i “sovetskii fol'klor” ["Stalin's falcons”: totalitarian phraseology and "Soviet folklore”]. In: Russkii politicheskii fol'klor: issledovaniia i publikatsii: sbornik [Russian political folklore: research and publications: collection], ed. by T. Grigor'eva. Moscow, Novoe izdatel'stvo Publ., 20I3, pp. III-II9. (In Russ.)

Kuznetsova V.P. Ekspeditsii K.V. Chistova v Karelii [K.V. Chistov's expeditions in Karelia]. Kunstkamera, 20I9, no I (3), pp. 23-35. (In Russ.)

9 Loiter S. M. Detskii poeticheskii fol'klor Karelii: issledovanie i teksty [Children's poetic folklore of Karelia: research and texts]. Petrozavodsk, Izdatel'stvo PetrGU Publ., 2013. 440 p. (In Russ.) Makurov V.G. Petrozavodsk v gody surovykh ispytanii I94I-I945 [Petrozavodsk in the years of severe trials, I94I-I945]. Petrozavodsk, Paritet Publ., 2005. 79 p. (In Russ.) Markovskaia E.V. Lagernyi fol'klor perioda finskoi okkupatsii Karelii (I94I-I944) [Camp folklore during the Finnish occupation of Karelia (I94I-I944)]. Traditsionnaia kul'tura, 2015, no 2 (58), pp. I9-27. (In Russ.) 

Karelia]. Fol'klor: struktura, tipologiia, semiotika, 20I8, vol. I, no I-2, pp. 43-54. (In Russ.)

I3 Miller F. Stalinskii fol'klor [Folklore in Stalin time]. St. Petersburg, Akademicheskii proekt; DNK Publ., 2006. I90 p. (In Russ.)

I4 Mironova V.P. Fol'klornye novoobrazovaniia v repertuare karel'skikh skazitelei I930I940 godov [New folklore formations in the repertoire of Karelian storytellers of the I930s-I940s]. In: Muzykal'naia traditsiia Severnoi Karelii [Musical tradition of North Karelia]. Petrozavodsk, Izdatel'stvo PGK Publ., 2013, pp. 50-57. (In Russ.)

I5 Propp V.Ia. Ob istorizme russkogo fol'klora i metodakh ego izucheniia [On the historicism of Russian folklore and methods of its study]. In: Uchenye zapiski LGU [Scientific notes of Leningrad State University]. Leningrad, Izdatel'stvo LGU Publ., I968, no 33, series: filologicheskie nauki [Philological Sciences], vol. 72, pp. 5-25. (In Russ.)

I6 Sen'kina T.I. Zabytye i neizvestnye stranitsy istorii fol'kloristiki Karelii. Ocherki i materialy [Forgotten and unknown pages of the history of folklore of Karelia. Essays and materials]. Petrozavodsk, Izdatel'stvo KarNTs RAN Publ., 20I2. 2I8 p. (In Russ.)

I7 Honko L. Itkuvirsirunous [Weeping poetry]. Suomen kirjallisuus [Finnish literature], edited by Matti Kuusi. Helsinki, Otava, Suomalaisen Kirjallisuuden Seura ja Otava Publ., I963, vol. I, pp. 8I-I24. (In Finnish)

I8 Markovskaja E.V. On the experience of creating genre classification of folkloric materials for electronic catalog of folkloric archival depository of ILLH KarRC RAS. European journal of literature and linguistics, 20I6, no 4, pp. 68-73. (In English) 